\title{
CORRELATION BETWEEN COPING MECHANISM AND SAFETY BEHAVIOR IN CONSTRUCTION WORKERS OF FABRICATION DIVISION IN A STEEL CONSTRUCTION COMPANY
}

\author{
Noeroel Widajati, Tri Martiana, Mulyono \\ Department of Occupational Safety and Health \\ Faculty of Public Health, Universitas Airlangga
}

\begin{abstract}
ABSTRAK
Perilaku yang tidak aman menjadi penyebab terbanyak terjadinya kecelakaan kerja. Salah satu faktor manusia penyebab terjadinya kecelakaan kerja adalah stres kerja. Tujuan dari penelitian ini adalah untuk menganalisis hubungan mekanisme coping dengan kejadian safety behavior pada pekerja bagian fabrikasi di perusahaan konstruksi baja. Penelitian dilakukan dengan rancangan cross sectional serta metode observasional dan analitik. Populasi penelitian adalah 200 pekerja di bagian fabrikasi perusahaan konstruksi baja. Dengan metode simple random sampling, maka jumlah sampel penelitian adalah 134 responden. Pengambilan data dilakukan dengan metode observasi, wawancara, dan kuesioner. Variabel bebas penelitian adalah usia, tingkat pendidikan, masa kerja, pengalaman K3, mekanisme coping, emotional focused coping, dan problem focused coping, sedangkan variabel terikat penelitian adalah safety behavior. Hubungan antar variabel diuji menggunakan uji Chi-square $(\alpha=0,05)$. Hubungan antara usia dengan safety behavior termasuk pada kategori berhubungan $(p=0,016 ; r=0,301)$. Hubungan antara tingkat pendidikan dengan safety behavior termasuk pada kategori tidak berhubungan $(p=0,260 ; r=0,315)$. Hubungan antara masa kerja dengan safety behavior termasuk pada kategori berhubungan ( $p=0,001 ; r=0,422)$. Hubungan antara mekanisme coping dengan safety behavior termasuk pada kategori tidak berhubungan $(p=1,0 ; r=0,015)$. Kesimpulannya adalah usia dan masa kerja memiliki hubungan searah dan kuat dengan safety behaviour, sedangkan tingkat pendidikan dan mekanisme coping tidak berhubungan dengan safety behaviour. Perusahaan harus memberikan pemahaman kepada pekerja tentang safety behaviour melalui pelatihan K3 dan safety talk dan melakukan safety inspection dan atau safety patrol untuk melihat safety behaviour pekerja. (FMI 2016;52:122-126)
\end{abstract}

Kata kunci: mekanisme coping, safety behaviour

\begin{abstract}
Unsafe act become the most cause of accidents. One of human factors causing accidents is work stress. The aim of this study was to analyze correlation between coping mechanism and safety behavior at workers of fabrication division in a steel construction company. The study was carried out with cross-sectional analytical observational methods. The study population was 200 workers of fabrication division in a steel construction company. By using simple random sampling method, the number of samples was 134 respondents. Data collection was performed by observation, interviews, and questionnaires. The independent variables were age, education level, K3 experience, coping mechanism, emotional focused coping, and problem focused coping, while the dependent variable was safety behavior. Intervariables correlation were tested by Chi-square test $(\alpha=0.05)$. Correlation between age and safety behavior was categorized on relation $(p=0.016 ; r=0.301)$. Correlation between education level and safety behavior was not categorized on relation $(p=0.260 ; r=0.315)$. Correlation between tenure and safety behavior was categorized on relation ( $p=0.001$; $r=0.422$ ). Correlation between coping mechanism and safety behavior was not categorized on relation $(p=1.0 ; r=0.015)$. The conclusion was age and tenure have unidirectional and strong relation with safety behavior, while the level of education and coping mechanism have no relation with safety behavior. Company should have given understanding to workers about safety behavior through K3 training and safety talk and held safety inspection and or safety patrol to supervise workers. (FMI 2016;52:122-126)
\end{abstract}

Keywords: coping mechanism, safety behavior

Correspondence: Noeroel Widajati, Department of Occupational Safety and Health, Faculty of Public Health, Universitas Airlangga e-mail: noeroel2014@yahoo.co.id

\section{INTRODUCTION}

Bureau of Labor Training (BPTK 2010) reported that workplace accidents are mostly caused by unsafe behavior. The percentage of causes of accidents, namely $3 \%$ for reasons which cannot be avoided (such as natural disasters), besides $24 \%$ due to environment or equipment that do not qualify, and $73 \%$ due to unsafe behavior or human factors (BPTK 2010). The human factor has a role where the men as the actors work has many shortcomings, such as lack of knowledge, lack of skills, motivation is not good, physical and mental stress causes a work accident occurred, resulting not only working conditions, but human beings as well as 
operators have many disadvantages (Suma'mur 1989). BPJS (Social Security Agency) Employment East Java province reported in 2013, work accidents most was Gresik which 43 people died of the 310 workers who died in the entire region of East Java and accident cases was mostly in the age range between 21 years to 35 year.

According to research Baker (2011), one of the causes of accidents are the source of job stress. One cause of work stress is the pressure of work. Heavy work pressure and pressed for time to finish the job may become stressful job so that these events can decrease the body's resistance to disease. As a result, workers tend to be frequent and less susceptible to disease so as to concentrate the work. An event like this can improve the appearance of errors work. Errors in accomplishing such work can be risky accidents. According to research conducted by Suprapto (2008) describes the symptoms of job stress consisting of psychological and physiological symptoms. Psychological symptoms have the greatest role to affect the risk of workplace accidents. This shows the effective contribution of psychological symptoms correlated with the risk of occupational accidents as much as $32.2 \%$ of the 50 respondents surveyed (Suprapto 2008).

According to NIOSH view, exposure to stressful working conditions (called job stressors) can have a direct effect on the safety and health of workers. Situational factors and the individual can strengthen or weaken the effect of this. Examples of situational factors and the individual (personal) that can help to reduce the effects of the conditions of work stress is called stress coping, can be in the form of support from coworkers or family, seek wisdom behind problems facing individuals, a positive outlook and a face without a load.

Work stress experienced by different people depending on how the individual is facing stressors called coping. When people get a stressor in the workplace, according to Lazarus \& Folkman (1984) Coping is the process of managing demand (external or internal) that is rated beyond one's sources. Coping has been known as a mediator of the demands of work and workers. Coping done to resolve the problem and balance the emotions of individuals in stressful situations. Theories regarding coping strategies are more comprehensively described by Lazarus \& Folkman (1984), which is generally argued that the coping strategy is divided into two forms of the strategies used to solve problems that cause stress (problem-focused coping) and coping strategies to cope with negative emotions accompaniments (emotionfocused coping). Coping mechanisms tend toward the emotion where most of the workers are more likely to have an impact on unsafe behavior in the workplace, such as smoking, taking drugs during work, listening to music on mobile phones, and frolic. This condition occurs in workers in the fabrication of heavy equipment at risk all for work accidents.

\section{MATERIALS AND METHODS}

Based on the classification, this study is an analytic research with an observational study since researchers only make observations and measurements without treatment or interaction with respondents. Based on the study design, including a cross-sectional study, observation and measurement of independent variables and the dependent variable will be combined and implemented in a short period of time and simultaneously. This study aims to analyze how much the relationship mechanisms of coping with the incident safety behavior on the part of workers in the fabrication of steel construction company. The population is all part fabrication workers than 200 workers at the fabrication of steel construction company. The sample in this study a number of 134 respondents were taken by simple random sampling. Data were analyzed descriptively in the form of frequency tables and cross tabulation then performed statistical tests using Chi-Square test with $\alpha=0.05$.

\section{RESULTS}

Table 1. Age distribution in workers of fabrication division in a steel company, year 2015

\begin{tabular}{ccc}
\hline Age Classification & $\begin{array}{c}\text { Total } \\
\text { (persons) }\end{array}$ & $\begin{array}{c}\text { Percentage } \\
(\%)\end{array}$ \\
\hline 19 to 29 years & 23 & 39.70 \\
30 to 49 years & 35 & 60.30 \\
50 to 64 years & 0 & 0 \\
\hline Total & 58 & 100 \\
\hline
\end{tabular}

Table 2. Sex distribution in workers of fabrication division in a steel company, year 2015

\begin{tabular}{|c|c|c|}
\hline Sex & $\begin{array}{c}\text { Total } \\
\text { (persons) }\end{array}$ & $\begin{array}{c}\text { Percentage } \\
(\%)\end{array}$ \\
\hline Male & 58 & 100 \\
\hline Total & 58 & 100 \\
\hline
\end{tabular}

The relationship of age to the safety related behavior in the category. It is based on tests conducted acquired great significance for 0.016 with the stronger the relationship category indicated by the contingency coefficient 0.301 . Relations with the education level of safety behavior in the category are not related. It is based on tests conducted acquired a significance of 
0.260. Great relationship with the stronger category indicated by the contingency coefficient 0.315 .

Table 3. Tenure distribution in workers of fabrication division in a steel company, year 2015

\begin{tabular}{lcc}
\hline Tenure & $\begin{array}{c}\text { Total } \\
\text { (persons) }\end{array}$ & $\begin{array}{c}\text { Percentage } \\
(\%)\end{array}$ \\
\hline 1 to 7 years & 43 & 74.10 \\
8 to 15 years & 13 & 55.56 \\
16 to 23 years & 2 & 3.40 \\
\hline \multicolumn{1}{c}{ Total } & 27 & 100 \\
\hline
\end{tabular}

Table 4. Level of education distribution in workers of fabrication division in a steel company, year 2015

\begin{tabular}{|c|c|c|}
\hline $\begin{array}{c}\text { Education } \\
\text { level }\end{array}$ & $\begin{array}{c}\text { Total } \\
\text { (persons) }\end{array}$ & $\begin{array}{c}\text { Percentage } \\
(\%)\end{array}$ \\
\hline SMP & 4 & 6.90 \\
\hline SMA & 27 & 46.60 \\
\hline D1 & 4 & 6.90 \\
\hline D3 & 15 & 25.90 \\
\hline D4 & 4 & 6.90 \\
\hline S1 & 4 & 6.90 \\
\hline Total & 58 & 100 \\
\hline
\end{tabular}

Table 5. Coping mechanism distribution in workers of fabrication division in a steel company, year 2015

\begin{tabular}{lcc}
\hline \multicolumn{1}{c}{ Coping mechanism } & $\begin{array}{c}\text { Total } \\
\text { (persons) }\end{array}$ & $\begin{array}{c}\text { Percentage } \\
(\%)\end{array}$ \\
\hline Almost always & 0 & 0 \\
Quite often & 55 & 94.80 \\
Very rarely & 3 & 5.20 \\
Almost never & 0 & 0 \\
\hline \multicolumn{1}{c}{ Total } & 58 & 100 \\
\hline
\end{tabular}

Table 6. Safety behavior distribution in workers of fabrication division in a steel company, year 2015

\begin{tabular}{lcc}
\hline Coping mechanism & $\begin{array}{c}\text { Total } \\
\text { (persons) }\end{array}$ & $\begin{array}{c}\text { Percentage } \\
(\%)\end{array}$ \\
\hline Almost always & 21 & 36.20 \\
Quite often & 37 & 63.80 \\
Very rarely & 0 & 0 \\
Almost never & 0 & 0 \\
\hline \multicolumn{1}{c}{ Total } & 58 & 100 \\
\hline
\end{tabular}

Relations tenure with the safety behavior in the category relate. It is based on tests conducted acquired great significance for 0.001 with the stronger relationship category indicated by the contingency coefficient of
0.422. Relations with the safety behavior coping mechanism in the category are not related. It is based on tests conducted acquired great significance correlation of 1.0 with the weaker categories indicated by coefficient of 0.015 .

\section{DISCUSSION}

The results showed that the age and safety behavior has unidirectional relationship and getting stronger. This shows that the older the person, the more influence the behavior and attitudes. According Notoatmodjo (2003) that the determinant of a person's behavior can be influenced by factors inside and outside of a person. Age also shows one's emotional maturity level, where the higher the more mature age potentially emotional state. It makes a person with a higher age tend to be easier to regulate emotions, actions, and behavior.

The results of this study also showed that the majority of respondents are of childbearing age both mentally and physically to do the job. This indicates that most respondents have been able to overcome problems related to safety and health in the workplace. Respondents have been able to sort of behavior that gives good impact on safety and health in the workplace. Maturity age makes the respondents have a good safety behavior. Safety behavior of the respondents in that age makes respondents always introspective and more careful in their work and be able to consider those aspects that can affect performance in the workplace.

The results showed that the level of education and safety behavior unrelated. The education level indicates a person's knowledge relating to occupations do. According Notoatmodjo (2003) that knowledge is one of the aspects that influence the person's behavior. Theories Bloom (1956) explains that knowledge has a degree starting out, understanding, application, analysis, synthesis, and evaluation. The education level of respondents who mostly have the end of high school education allows respondents do not meet the six levels of knowledge. So it can not appear as a behavior that is the reaction of such knowledge.

Incomplete level of knowledge respondents tend not to produce safety behavior in doing the work., So as to complete the sixth level, the company is expected to pay more attention to working conditions and work. According to NIOSH (1998) that the design work, the characteristics of managerial, interpersonal relationships, roles and responsibilities at work, career development, and environmental conditions work is a cause of stress in the workplace, so as to bring up the coping 
mechanism so well that raises safety behavior that the company good for more attention to the working conditions of the various aspects.

The results showed that the period of employment with the safety behavior related to the direction and getting stronger. Future work tends to show one's experience in working. Work experience considerable help a person to behave in the workplace, including the behavior of adherence to health and safety. Someone with years of work experience and are quite able to learn from mistakes made in the work, for example, a friend of the workers fell from work at height, as a result of not wearing appropriate personal protective equipment eventually the worker suffered serious injuries. A worker with tenure and experience can learn from work accidents he experienced workers or friends. This will increase safety behavior at work.

Relations tenure with a direct safety behavior indicates that the longer the tenure, the higher the level of safety behavior at work. Someone with a long tenure tend to pay attention to the behavior of survivors in the workplace. It is based on a experience he gained while working with tenure sufficient. Someone with tenure who are quite capable of understanding things that happen around the workplace. According to Bloom Theory (1965) that an individual's understanding demonstrated in sorting out and do things in life. Application of the things gained from work experience with tenure are enough to make a person able to act correctly according to the norms and rules that apply in the workplace.

Coping mechanism is a person's ability to solve problems (stressor) in the workplace. According Keliat (1992) found that one may experience the stress of work and will seek a solution to deal with the stress experienced. Coping mechanisms are carried out on each individual self will affect the appearance of good behavior and not well in the workplace, particularly those related to occupational safety and health.

The results showed that the safety mechanisms of coping with behavior unrelated. It can be caused by factors both inside and outside of respondents do not support the emergence of safety behavior. Factors that affect a person's coping is physical health, confidence, skills in problem solving, social skills, social support, and material. These factors allow the respondent did not raise safety behavior at work. Another thing that can affect the respondent in conducting safety behavior is not obtained at the workplace so as to enable the respondent does not care about the safety and health. According to Green (1980) that behavior is influenced by predisposing factors, enabling factors and reinforcing factors. These three factors are not mutually supportive and does not give effect to the respondent. For example, the absence of the example of the use of personal protective equipment be workmen think that the use of PPE is not important, so (NOTE: there seems to be a miss in the paragraph, thus hampering the process of editing).

Respondents were mostly very attentive behavior towards health and safety in the workplace. Seniors with safety behavior has a strong unidirectional relationship and work, this does not raise safety behavior at the respondent. Always do the coping mechanisms of the problems that occurred the workplace, this does not raise safety behavior at the respondent shows that the older the better safety behavior in the workplace. Level of education and safety behavior is not related, this indicates that the level of education does not guarantee the safety of good or bad behavior in the workplace. Future work with safety behavior has a strong relationship and a handover that indicate that longer working lives, the better the safety behavior in the workplace. Coping with a safety mechanism unrelated behavior that indicates the level of stress experienced by the respondents and coping mechanisms are made to the stress experienced by the merits does not guarantee safety behavior in the workplace. (NOTE: there seemed to miss in paragraphs).

\section{CONCLUSION}

Most of the respondents aged 30 to 49 years, male gender, have a service life for more than 1 to 7 years, and have a high school education level. Most respondents almost (NOTE: there seemed to miss in paragraphs).

\section{REFERENCES}

Baker R (2011). Understanding Panic Attack and Overcoming Fear, England, Lion Hudson plc

Bloom BS (1956). Taxonomy of Educational Objectives Book 1: Cogntive Domain, 2nd ed, Boston, Addison Wesley Publishing Company

BPJS (Social Security Agency) (2013). Data Kecelakaan Kerja Jawa Timur, Surabaya

BPTK (Bureau of Labor Training) (2010). Data Kecelakaan Kerja, Jakarta, Balai Pelatihan Tenaga Kerja

Gordon NP (1986). the prevalence and health impact of shiftwork. American Journal of Public Health 76. Available from http://www.ajph.org/. Accessed January 22, 2013 
Green WL (1980). Health Education Planning: A Diagnostik Approach, 1st ed, California, Mayfield Publishing Company

Keliat BA (1992). Gangguan Konsep Diri, Jakarta, PB Kedokteran EGC

Lazarus RS and Folkman S (1984). Stress, Appraisal, and Coping, New York, Springer

Mohammad I (2009). The relationship between job stress and occupational accidents in an automobile manufacturing company. Journal of Khermanshah University of Medical Science

National Institute for Occupational Safety and Health (NIOSH) (1998). Stress At Work. Available from https://www.cdc.gov/niosh/docs/99-101/. Accessed January 22, 2013

Notoatmodjo S (2003). Pendidikan dan Perilaku Kesejatan, Jakarta, Rineka Cipta

Pratiknya W (2007). Dasar-dasar Metodologi Penelitian Kedokteran dan Kesehatan, Jakarta, PT Raja Grafindo Persada
Rasmussen J (1982). Human errors: a taxonomy for describing human malfunction in industrial installations. Journal of Occupational Accidents 4

Samosir ZZ and Syahfitri I (2008). Faktor penyebab stres kerja pustakwan pada perpustakaan Universitas Sumatera Utara. Jurnal Studi Perpustakaan dan Informasi 4, 60-69

Sauter S, Hurrell J, Murphy L, Levi L (1997). Psychosocial and organizational factors. In: Stellman J (ed). Encyclopaedia of Occupational Health and Safety Vol 1, Geneva, International Labour Office

Suma'mur. (1989). Higiene Perusahaan dan Kesehatan Kerja (Hiperkes), Jakarta, Sagung Seto

Suprapto HPP (2008). Hubungan antara stres kerja dengan risiko kecelakaan kerja pada karyawan. Bachelor Thesis. Universitas Islam Indonesia, Yogyakarta 